have worked in Indonesia, Uganda, and Korea. Barred from surgery in the United Kingdom, in Indonesia I found myself in sole charge of a 300-bedded hospital with around 200 outpatients a day, responsible for the surgery, medicine, obstetrics, etc., for a. population of 45,000 persons, the only doctor in a large tract of land. Thus it is interesting to note that the Interview Board believes that non-specialists who undertake surgery add considerably to their income and interest, but that it "cannot always be in the best interest of the patients." I agree that the practice of surgery adds to one's interest, but working for the impoverished Indonesians I considered myself fortunate to receive the equivalent of $7 \mathrm{~s}$. $6 \mathrm{~d}$. for a radical mastectomy. Further, I wonder on what grounds the Board slurs the work of the nonspecialist surgeons in North America. Were the patients seen and examined? Were the " surgeons" watched at work? I note there was no surgeon on the Board. Or is it just that the non-possession of a higher surgical degree makes one so inferior that one is unable to help one's fellow men?

Recently many views have been advanced to account for the drain, but there is one view I have not yet seen in print. In many instances surely the emigration is only partly caused by a dissatisfaction with medical matters in the United Kingdom. The "medical" dissatisfaction is combined with a greater or equally great complete disenchantment with the United Kingdom as a whole. It is no light decision to leave the country of one's birth with the firm intention of not returning, and I seriously doubt if a mere dissatisfaction with purely professional matters would provide a sufficient stimulus. Your leading article (6 January, p. 1) stated that most of the interviewed emigrants in North America now wished to return for the benefit of their children. Thus they originally left their country for their profession but now renounce their better professional opportunities for their children. Many hundreds of us, however, prefer to keep our new and better lives and to send our children to boarding-schools in the United Kingdom. - I am, etc.,

Francis M. Shattock.

Save the Children Fund,"

Pusan, Korea.

\section{Prescription Charges}

SIR, - We understand on reading the papers today ( 5 March), the source of most of our information on the N.H.S. these days, that patients exempt from payment for prescriptions are to be issued with embossed cards by the executive councils. Machines are to be distributed to chemists and dispensing doctors by which details on these cards are to be transferred to the backs of prescription forms at the same time as the drugs are given to the patient. No doubt this matter will be debated in due course by executive councils and local medical committees, but we fear that we have been presented with a fait accompli and no amount of debating will alter it.

Our purpose in writing is to draw attention to the complications which will arise in large dispensing practices such as our own. We issue drugs from the main surgery, where there is ancillary staff, from two branch surgeries (no ancillary staff), from our cars when visiting patients in distant villages with no bus services, and from our own houses when we are on duty at week-ends. Can you imagine the chaos if every time a drug is issued and a prescription written for an exempt patient we have to stamp the patient's embossed card on to the prescription form ? If we do not no doubt we shall be liable for finding the $2 \mathrm{~s} 6 \mathrm{~d}$. from our own pockets.

This system will be difficult (and costly) enough for chemists to work. For dispensing doctors it will be well-nigh impossible, unless there is to be serious curtailment of existing services to patients in outlying rural areas. The machines would have to be carried from the doctor's car to the patient's house (or the patient will have to bring his card to the car to be stamped) and from the doctor's car to each branch surgery. Even then we estimate that in our practice a minimum of four stamping machines will be necessary.

We write as doctors strongly in favour of making charges to patients who can afford it We are willing to go to a lot of trouble to support this fundamental principle. But we have the gravest doubts about the practicability of the scheme outlined to us in today's papers. Is it worth it ?-We are, etc.,

$\begin{array}{ll}\text { Yaxley, } \\ \text { Peterborough. } & \text { C. J. HART. } \\ & \text { I. H. REDHEAD. }\end{array}$

SIR,-The problem of introducing prescription charges with specified exemptions is impossible to solve perfectly fairly. Certain categories of chronicity are well defined and require either continuous therapy or frequen enough courses of therapy to present no difficulty.

It is the recurrent conditions and those with frequent remissions which are difficult to assess-namely, urinary infections and respiratory infections such as chronic bronchitis. Both of these do not start off by being chronic, and there is usually no clearcut delineation between the acute stages and the chronic. In order to cover these with exemptions from charges some sort of qualifying conditions must be applied which can relate only to the number and frequency of attacks, duration, or severity, which of course only the doctor can assess. It is difficult to apply a mere name to an exempted condition, since the onus is still on the doctor to classify it, and the onus should not be on the doctor to decide how to apply Government decisions. Conditions like neurosis can be extremely difficult to assess.

Schemes of this sart should be cut-anddried before announcement of intention to apply them. It will be simpler and probably not much dearer to drop the scheme altogether.-I am, etc.,

Cambridge.

\section{K. B. HALIAM.}

SIR,-I read with dismay the announcement that patients exempted from paying prescription charges are to have embossed cards issued to them (at a cost of several hundred thousand pounds), and that the chronic sick are to be determined by Ministry definition only.

Surely the general practitioners in Britain can be trusted to decide which patients are "chronic sick" within definitions laid down by the Ministry and from their experience of the patient. Furthermore, should a chronic sick patient with rheumatoid arthritis, for example, be given a free prescription for cough linctus when they catch a cold ?

A simpler, inexpensive system would consist in issuing all practitioners with E.C.10s printed on a different-cołoured paper entitling the recipient to free drugs prescribed thereon. The white paper E.C.10s already issued would continue to be used for items which have to be paid for.-I am, etc.,

$$
\begin{aligned}
& \text { Gosport, } \\
& \text { Hampshire. }
\end{aligned} \text { J. E. GodRICH. }
$$

SIR,-As a dispensing doctor I look forward with the utmost alarm to the intro duction of prescription charges. Experience in the past showed that it was distasteful and troublesome to a degree. Distasteful because patients regarded it as a direct pay. ment for services rendered, and nothing would convince them that it was a tax. One soon wearied of explanations to the question, "How much do I owe you, doctor?" Troublesome because of the difficulties of collection. Arrangements had to be made when leaving medicine to be collected, ofter at outlying points. It was irksome to be continually handling grubby heaps of pence and halfpence, to give change for $£ 1$ notes, to be stopped continually when out with patients proffering long-forgotten owed sums. Still troublesome when all the cash was stolen, as happened to me on three occasions. Now we are to have all this again and in addition we will no doubt have to decide who is exempt, to account for our decisions, to issue exemption cards and so forth, as in our case there is no pharmacist to do it for us

We are a small group, perhaps 700 in all but we believe we render a service to the community in rural areas. We met in Witney some time ago and achieved a usefu' unity of opinion. Is it not time we mel again ?-I am, etc.,

Tenterden.

B. W. WYLLIR.

Kent.

\section{Points from Letters}

\section{Records in General Practice}

Dr. A. J. Laidiaw (Thorneloe Lodge, 29 Barbourne Road, Worcester) writes: I have been awarded an Upjohn Travelling Fellowship by the Royal College of General Practitioners to study records in general practice. This study will mainly be concerned with medical records, but all other forms of recording, administration. etc., will be included. I would be pleased to hear from anyone who can be of assistance to me in this study.

\section{Prescription Charges}

Dr. L. A. PYRe (Birmingham) writes: It has not yet been revealed how some patients with chronic illnesses are to be exempted from pay ment of prescription charges. In this practice of 7,500 patients there are 2,020 under the age of 16 and 838 over the age of 65 , so that $40 \%$ of the practice are exempt for this reason. This $40 \%$, however, produce $50 \%$ of the consultations. How chronic illness is to be defined we are yet to find out. In addition, about 150 patients receive antenatal care at any one time, and presumably these will also be exempt from prescription charges. 